\title{
OPTIMIZATION OF SEA WATERWAY SYSTEM PARAMETERS IN MARINE TRAFFIC ENGINEERING OPTYMALIZACJA PARAMETRÓW SYSTEMU
MORSKICH DRÓG WODNYCH W UJECCIU INŻYNIERII
RUCHU MORSKIEGO
}

\section{Stanisław Gucma}

Maritime University of Szczecin, Marine Traffic Engineering Centre

e-mail:s.gucma@am.szczecin.pl

\begin{abstract}
The article defines a system of sea waterways and discusses general principles of modeling such systems. Conditions for safe operation of marine waterway systems are specified. The author's model of waterway parameter optimization herein presented was used in designing a system of approach channels leading to the outer port in Świnoujście, the LNG terminal.
\end{abstract}

Keywords: marine traffic engineering, marine waterways

Streszczenie: $W$ artykule zdefiniowano system morskich dróg wodnych oraz przedstawiono ogólne zasady jego modelowania. Określono warunki bezpiecznej eksploatacji systemu morskich dróg wodnych oraz zbudowano model optymalizacji jego parametrów. Opisany model optymalizacji zastosowano przy projektowaniu systemu podejściowych dróg wodnych do portu zewnętrznego $w$ Świnoujściu (Terminalu $L N G$ ).

Stowa kluczowe: inżynieria ruchu morskiego, morskie drogi wodne 
Optimization of sea waterway system parameters in marine traffic engineering Optymalizacja parametrów systemu morskich dróg wodnych...

\section{Introduction}

A system of sea waterways from the marine traffic engineering perspective consists of a number of separate sections. Each waterway section features two basic components:

- waterway subsystem;

- ship position determination system (navigational subsystem).

Both subsystems are interrelated and have an essential influence on the system properties. Waterway sections are distinguished on the basis of the following comparative criteria:

- manoeuvre performer;

- technical parameters of the waterway;

- technical parameters of navigational systems;

- prevailing hydrometeorological conditions;

- port regulations.

The waterway system function is to provide conditions for a ship with specific parameters to perform a planned manoeuvre. The input quantity of the system is a planned manoeuvre of a ship with specific parameters, the output is the manoeuvre performed by that ship. Marine traffic engineering uses a cybernetic definition of the system [3]. Such systems are relatively separate, which as a whole are coupled with the environment through input and output quantities [5]. A waterway system is a man-made system where boundaries between the system and its model are not clearly defined. A general model of waterway system is shown in Figure 1.

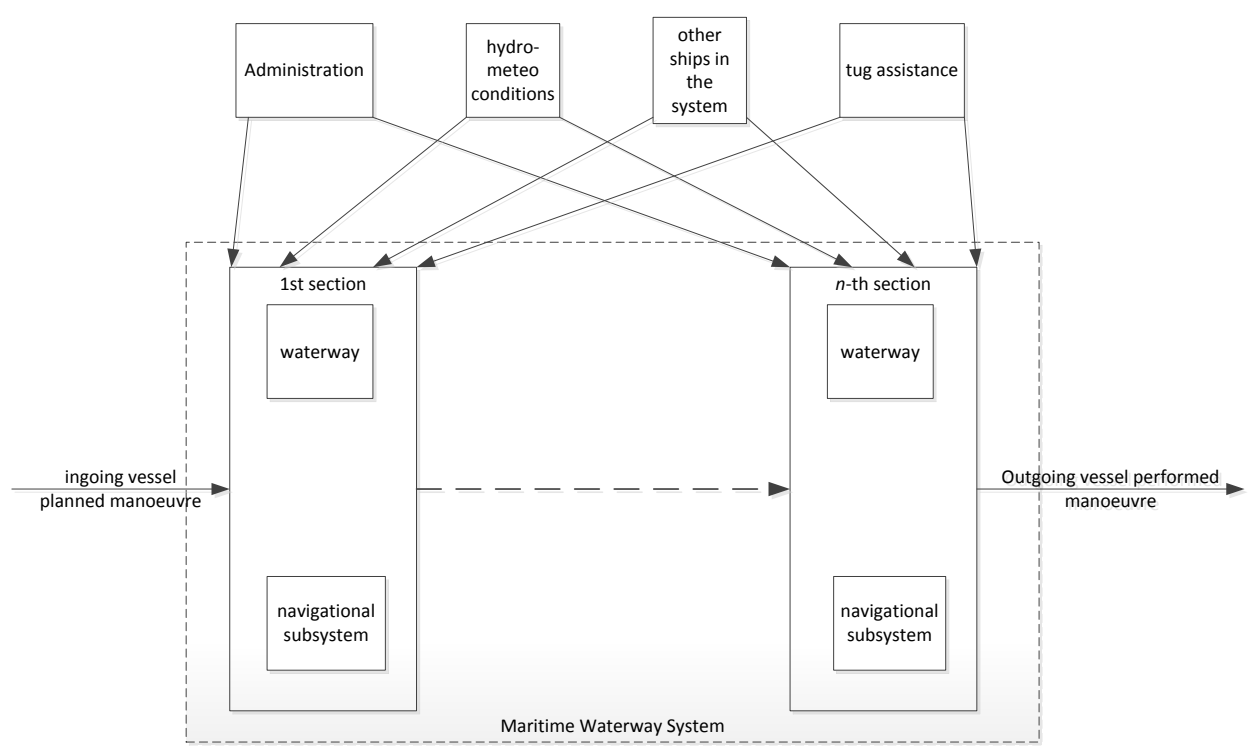

Fig. 1 A general model of waterway system with $n$ sections 
One of the sea waterway design stages is parameter optimization. Parameters of the sea waterway system are of two types: parameters of navigable area of a given waterway section and parameters of the ship position determination subsystem within that section.

The navigable area parameters of a waterway are as follows:

- area depth;

- horizontal dimensions of the area determined for a preset depth contour.

Parameters of position determination subsystems within a waterway section are these:

- availability;

- reliability;

- accuracy.

The stage of waterway parameter optimization is preceded by the identification of conditions for safe operation of the system.

\section{Conditions of safe operation of sea waterway system}

The conditions for sea waterway system operation to be safe can be divided into operational conditions of the waterway subsystem and those of navigational subsystem.

The establishment of conditions of waterway operation consists of the following actions [4]:

1) Division of the waterway into characteristic sections; these are defined on the basis of:

- parameters of each section (depths and available channel widths);

- types of manoeuvres performed in these sections;

- hydrometeorological conditions prevailing within these sections;

- type of navigational marks used within each section.

2) Defining of hydrometeorological conditions prevailing in each section and their impact on the safety of manoeuvres to be performed there.

3) Determination of the parameters of a 'maximum ship' expected to operate on a given waterway; the main particulars are:

- length (length overall $L_{c}$ and length between perpendiculars $L_{p p}$ ),

- breadth $(B)$,

- maximum draft $(T)$.

A 'maximum ship' is defined as the largest ship that under assumed navigational conditions may safely manoeuvre on the examined waterway (i.e. pass it safely). Therefore, if only one parameter reaches that of a 'maximum ship', the ship will be regarded as a maximum ship [1].

Additional relevant parameters of a ship are:

- allowable speed,

- type of ship characterized by its block coefficient. 
Ships proceed along a waterway at various allowable speeds, that depend on the type of the area and the ship itself. On the one hand these speeds are imposed by operating requirements resulting from time restrictions of such vessels as container ships, Ro-Ro vessels or gas tankers, on the other hand ship's speed has to assure navigational safety. This is usually 'a service speed in restricted areas' at which ships proceed in distant roadsteads and anchorage approaches or a 'reduced speed' along dredged fairways. The service speed in restricted areas is developed at the engine setting 'manoeuvring full ahead'. The reduced speed is developed at the engine set for 'half ahead'.

4) Determination of basic operating conditions for a 'maximum ship' in each waterway section - conditions allowing the ship to keep passing the fairway.

These conditions include:

- time of day (e.g. no restrictions or daylight);

- visibility (no restrictions, or e.g. $s \leq 2 \mathrm{Nm}$ );

- ship's maximum speed;

- allowable wind speed;

- wind direction;

- allowable current speed;

- current direction;

- wave height;

- wave length;

- clearance for minimum water level;

- ice situation;

- tug assistance (type).

The minimum water level clearance is determined depending on ship type, minimum water level and the probability of its occurrence, and the operation period of the designed waterway. This clearance is determined for two groups of ships: those that cannot wait for a higher water level and those that can. For the former: ferries, gas tankers, liners, etc., the minimum water level is assumed as it occurs in a 20-year period of waterway operation (lifetime period adopted for this type of investment project). For the ships that can wait for water to rise, the assumed minimum water level is that occurring over a five-year period.

The following guidelines should be taken into account while defining operating conditions for the navigational subsystem [4]:

1) Navigational systems (systems of ship position determination) on a given waterway are designed separately for each group of ships by size.

2) Design of the systems should start from 'maximum ships', because it often turns out that the requirements for systems serving small ships are also met by systems for large ships [2].

3) Systems of position determination are designed for these three visibility conditions:

- daylight (good visibility); 
- night (good visibility);

- poor visibility.

Note that operating assumptions for the waterway under consideration may restrict the number of design conditions for specific ship size groups. For instance, certain ships can navigate along the waterway only at daylight, or navigation along a given waterway can take place only in good visibility.

4) Systems of position determination for the three types of visibility conditions have to be doubled, otherwise a failure of one position determination system creates a threat of navigational disaster. Two navigational systems have to be designed for each of the three visibility conditions:

- main system;

- additional system.

5) Designed ship position determination systems on a given waterway have to satisfy these requirements:

- availability;

- reliability;

- accuracy.

The availability of ship position determination system depends on the ownership status and prevailing hydrometeorological conditions. Factors or situations to be considered in this relation include:

- disconnection of navigational lights by their owner,

- hydrometeorological conditions in which certain position determination systems are not available, refer to: restricted visibility $(s<2 \mathrm{Nm})$, at which terrestrial (optical) methods) are not available, or ice situation, where seamarks are normally removed,

- extreme hydrometeorological conditions, in which the whole waterway system is inaccessible for a given ship, are defined by vessel operating conditions within the waterway under consideration, e.g. exceeded wind speed or wave height.

The reliability of position determination of a vessel is its ability to obtain a position with specific accuracy. This technical reliability is estimated by the intensity of failures of system components. Defects of the system components decrease the assumed accuracy or make position determination impossible. The probability of system component reliability is calculated by using the failure intensity function $\lambda(t)$ at instant $t$, the density function of the failure under a condition that till that instant there was no failure [1]. Issues to be considered in relation to reliability are as follows:

- reliability of satellite or radionavigation methods (e.g. pilot navigation system) depends on technical faults of the system (its software and hardware);

- reliability of optical methods may be affected by seamarks getting adrift or failure of lights in the night; 
Optimization of sea waterway system parameters in marine traffic engineering Optymalizacja parametrów systemu morskich dróg wodnych...

- reliability of radar methods may be affected by floating seamarks adrift (technical reliability due to radar fault will not fail as the ship is equipped with two radars working on hot redundancy basis).

The accuracy of ship position determination system is defined via the width of safe manoeuvring area, described by the function of position determination accuracy, thus by the parameters of the systems. Therefore,

$$
d=f\left(d_{n}\right)
$$

consequently,

$$
d=f\left(N_{i}\right)
$$

where:

$d$ - width of safe manoeuvring area;

$d_{n}$ - navigational component of safe manoeuvring area width;

$N_{i}$ - parameters of the position determination system.

Assurance of properly high level of manoeuvring safety in fairways is a major task in designing waterways and defining operating conditions. This task comes down to the determination of navigable area parameters within waterways and parameters of navigational systems used therein for manoeuvring. The vessel can manoeuvre safely only within an area that at each point satisfies the condition of required (safe) depth. Such area is a navigable area that can be represented as an area $\mathbf{D}$ of a set of points satisfying the condition of required depth at an instant $t$. A safe depth at the design stage or during waterway modernization is usually determined by the constant underkeel clearance method.

The vessel performing a manoeuvre within a navigable area occupies a certain area defined by its subsequent positions in the area. That area is called the safe manoeuvring area $\boldsymbol{d}$, and the principal condition for navigational safety can be written in this form [1]:

$$
d \subset \mathbf{D}
$$

\section{Optimization of sea waterway system parameters}

The following assumptions were made while determining the objective function in the problems of the optimization of waterway system parameters, construction or conversion costs of a given waterway element or elements and its navigational subsystem, as well as operating costs of these subsystems:

- examined 'maximum ship'; manoeuvres on the waterway, where its position is determined in a Cartesian coordinate system.

- examined area is defined by a set $\mathrm{x} \in \mathrm{X}, \mathrm{y} \in \mathrm{Y}$, comprising such subsets of the navigable area $\mathbf{X} \mathbf{1} \subset \mathbf{X}, \mathbf{Y} \mathbf{1} \subset \mathbf{Y}$; lines of berths $\mathbf{X} \mathbf{2} \subset \mathbf{X}, \mathbf{Y} \mathbf{2} \subset \mathbf{Y}$; lines of breakwaters $\subset \mathbf{X}, \mathbf{Y} \mathbf{3} \subset \mathbf{Y}$.

- coordinates describing these subsets are Cartesian products: $\mathbf{X} 1 \times$ Y1; X2 $\mathrm{x}$ Y2; X3 x Y3. 
- ships that can manoeuvre within the examined area belong to a set $i \in \mathbf{I}$. This refers to their size (length, breadth, draft), and to propeller power, types of propellers and manoeuvring characteristics.

- a ship manoeuvring on the examined waterway can perform one of the manoeuvres contained in a set $j \in \mathbf{J}$. This is a set of manoeuvre types performed on the examined waterway (number of manoeuvres, number and power of tugs used).

- examined ships can manoeuvre in navigational conditions comprised in a set $k \in \mathbf{K}$. This refers to both navigational subsystems and hydrometeorological conditions (wind/current directions and speeds, waves, visibility, ice situation, water level etc.).

- The conditions that determine the safety of navigation in this model are as follows:

- size of the navigable area;

- underkeel clearance.

Adopting the above assumptions and conditions, we can write the objective function of waterway parameters optimization in this form:

$$
Z=(A 1+A 2+N 1+N 2+S) \rightarrow \min
$$

where:

$$
\begin{aligned}
A 1 & =f_{1}\left(\mathbf{D}, h_{x y}\right), \text { while }(x, y) \in X 1 \times Y 1 ; \\
A 2 & =f_{2}\left(\mathbf{D}, h_{x y}\right) ; \\
N 1 & =f_{3}\left(\mathbf{D}, h_{x y}\right) \\
N 2 & =f_{4}(\mathbf{D}) ; \\
S & =f_{5}(\mathbf{D}) ;
\end{aligned}
$$

that is:

$$
Z=F\left(\mathbf{D}, h_{x y}\right) \rightarrow \min
$$

with one of the two constraints:

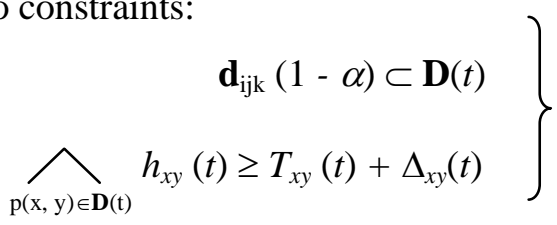

$$
\begin{aligned}
& \mathrm{R}_{\mathrm{l}} \leq \mathrm{R}_{\mathrm{akc}}
\end{aligned}
$$

where:

$\boldsymbol{D}(t) \quad-$ navigable area (safe depth condition at instant $t$ is satisfied);

$\boldsymbol{d}_{i j k}(1-\alpha)-$ safe manoeuvring area of $i$-th ship performing $j$-th manoeuvre in $k$-th navigational conditions, determined at a confidence level $1-\alpha$;

Z $\quad$ - cost of construction and maintenance of waterway system;

A1 - cost of waterway construction/conversion; 
Optimization of sea waterway system parameters in marine traffic engineering Optymalizacja parametrów systemu morskich dróg wodnych...

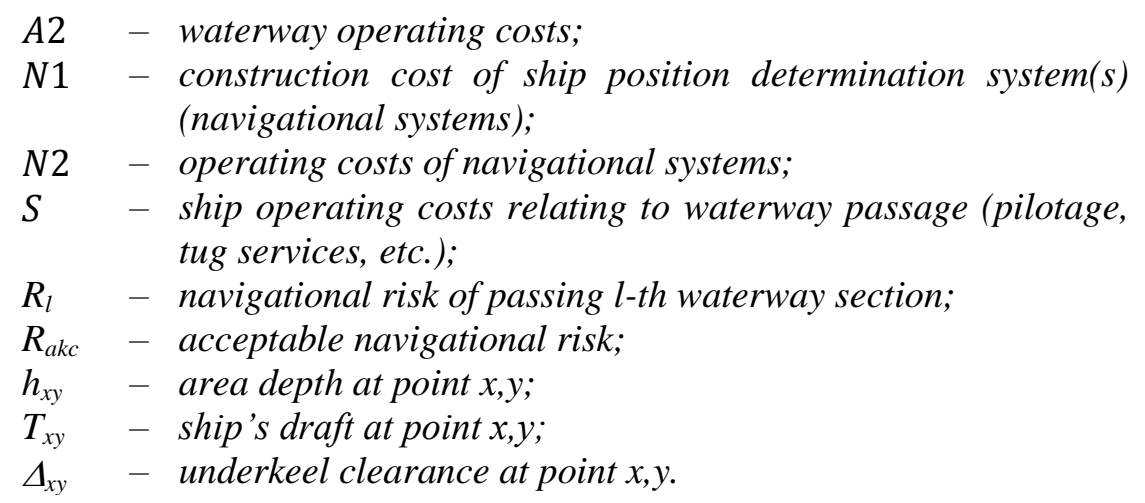

\section{Application of the developed model for the design of a system of approach waterways to the outer port świnoujście}

The presented method of the optimization of sea waterway system parameters was actually used in the design of approach channels leading to the LNG terminal in Świnoujście. The modernization of the approach channel in Świnoujście is related with the construction the outer port where a new LNG terminal is being built. The terminal will handle Q-Flex gas carriers, whose basic parameters are:

- length overall: $L_{c}=315 \mathrm{~m}$;

- breadth: $B=50 \mathrm{~m}$;

- draft: $T=12.5 \mathrm{~m}$.

Taking into account the operating conditions of LNG tankers in the Świnoujście outer port and design principles applying to waterway systems, the following guidelines were adopted:

1) basic methods of ship position determination are:

- satellite method used in a Pilot Navigational System (PNS) based on the DGPS system. The method is applicable regardless of the time of day or visibility;

- terrestrial (optical) method of position determination, using fixed and floating navigational marks. The method can be used at any time of day and in good visibility $s>2 \mathrm{Mm}$.

2) Additional (emergency) method of position determination is:

- radar method of position determination using fixed and floating navigational marks and 'point' shore-based radar facilities. The method is applicable regardless of the time of day or visibility.

3) Position determination methods to be used when a gas carrier is manoeuvring in an approach channel are as follows:

- PNS: at any time, regardless of time of day or visibility;

- terrestrial (optical): always in good visibility, regardless of time of day;

- radar: always as an additional method, and the main method if the PNS sustains failure or visibility is poor. 
With the above guidelines taken into consideration, the navigational component of the manoeuvring area for an LNG carrier was determined for various confidence levels depending on the ship position determination method [6]:
- PNS
$1-\alpha=0.997$
- terrestrial (optical)
- radar
$1-\alpha=0.997$
$1-\alpha=0.95$.

Figure 2 presents widths of the safe manoeuvring areas of each approach channel section leading to the port of Świnoujście for a Q-Flex gas tanker going in at 8 knots.

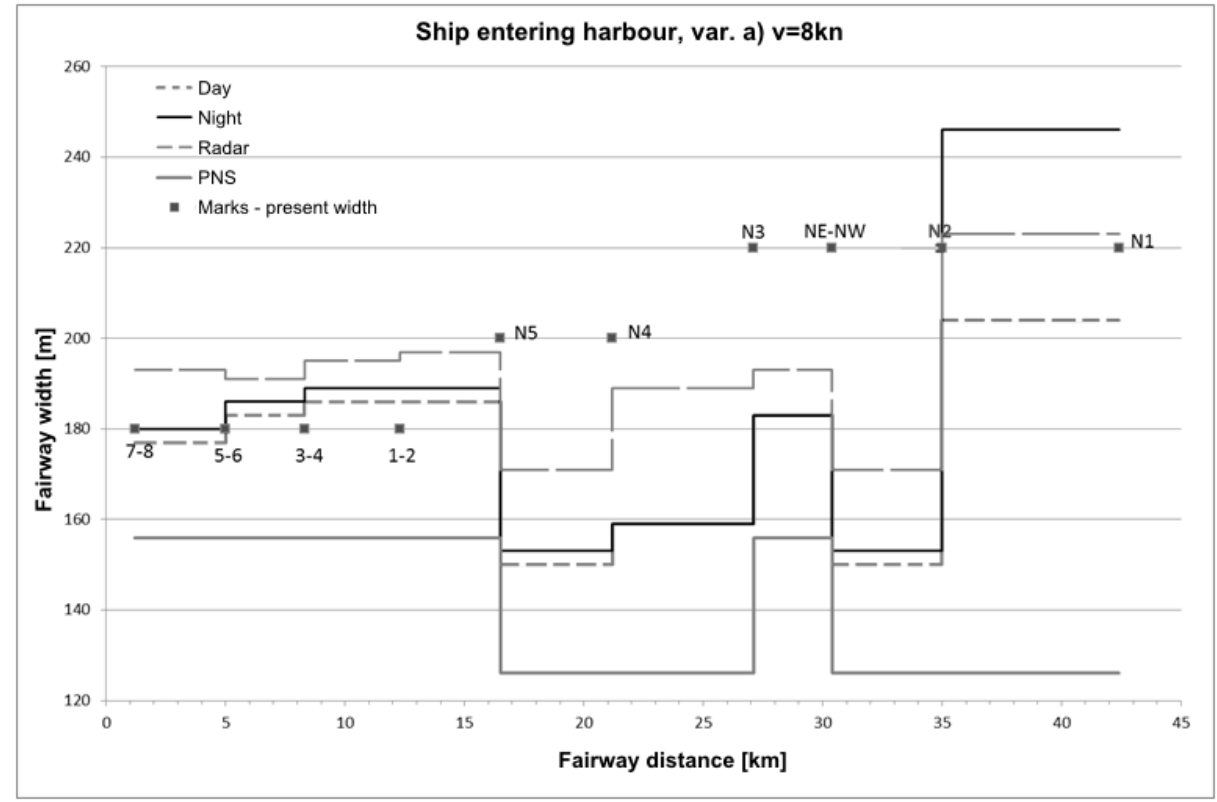

Fig. 2 Safe widths of the approach waterway for an LNG tanker (speed 8 knots) present buoyage status

The widths of safe manoeuvring areas at each section have been calculated for the following systems (methods) of ship position determination:

- terrestrial method - daylight;

- terrestrial method - night;

- radar method;

- method using a PNS.

Finally, using the cost minimization criterion relating to the conversion of the existing system of waterway approaches to the outer port in Świnoujście, for all the Q-Flex LNG carrier safety conditions satisfied, we determined the parameters of the waterway approach (minimum safe widths at bottom depth $h=14.5 \mathrm{~m}$ ) and parameters of the aids to navigation (sea and landmarks) [6].

The minimum safe width of the fairway at the bottom $14.5 \mathrm{~m}$ deep is:

- $200 \mathrm{~m}$ from $0.0 \mathrm{~km}$ to $26.8 \mathrm{~km}$ of the fairway;

- $220 \mathrm{~m}$ from $26.8 \mathrm{~km}$ to $35.6 \mathrm{~km}$ of the fairway. 
Optimization of sea waterway system parameters in marine traffic engineering Optymalizacja parametrów systemu morskich dróg wodnych...

The existing navigational marks were altered by establishing two new beacons and changing the position and types of the buoys.

\section{Conclusions}

The article defines a system of sea waterways composed of two elements:

- waterway subsystem;

- navigational subsystem.

Apart from building the system model, a method for the optimization of subsystems' parameters has been developed.

This is a new systematic approach to modeling and design of waterways.

The developed method has been used for the design of parameters of the waterway system leading to and out of the outer port in Świnoujście. The LNG terminal under construction in this port will be handling 315-metre Q-flex type gas tankers.

\section{Bibliography}

[1] Gucma Stanisław: „Inżynieria Ruchu Morskiego”, Wydawnictwo „Okrętownictwo i Żegluga”, Gdańsk 2001, ISBN 83-908796-6-2.

[2] Gucma Stanisław: „Nawigacja pilotażowa”, Wydawnictwo „Fundacja Promocji Przemysłu Okrętowego i Gospodarki Morskiej”, Gdańsk 2004, ISBN 83-919488-5-4.

[3] Gucma Stanisław, Gucma Lucjan i Zalewski Paweł: „Symulacyjne metody badań w inżynierii ruchu morskiego", Wydawnictwo Naukowe Akademii Morskiej w Szczecinie, Szczecin 2008, ISBN 978-83-89901-29-3.

[4] Gucma Stanisław, Ślączka Wojciech i Zalewski Pawel: „Parametry torów wodnych i systemów nawigacyjnych wyznaczane przy wykorzystaniu bezpieczeństwa nawigacji" Wydawnictwo Naukowe Akademii Morskiej w Szczecinie, Szczecin 2013, ISBN 978-83-89901-82-8.

[5] Gutenbaum Jakub: „Modelowanie matematyczne systemów”, Akademicka Oficyna Wydawnicza EXIT, Warszawa 2003, ISBN 83-87674-53-2.

[6] „Projekt systemów zapewniających bezpieczną nawigację i obsługę statków LNG na podejściu i w porcie zewnętrznym w Świnoujściu", praca naukowobadawcza, Akademia Morska w Szczecinie, Szczecin 2012.

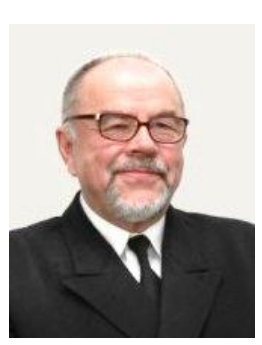

Prof. dr hab. inz. kpt. z. w. Stanislaw Gucma, Master Mariner, is professor at the Maritime University of Szczecin. He is the creator of the new scientific discipline in Poland: marine traffic engineering. An author of 11 books and over 170 scientific publications on the subject. Professor Gucma has been in charge of more than 120 research projects. Most of them were implemented in Poland and EU countries. Some projects were related to the largest maritime investments in Poland. A member of the Transport Committee of the Polish Academy of Sciences (PAN), Academy of Engineering in Poland and the Transport Committee of Russia. 